\title{
Adapting Hamlet to the Turkish Screen
}

Abstract: This article examines the only Turkish cinematic adaptation of Hamlet to date, entitled Kadın Hamlet: Intikam Meleği [Lady Hamlet: The Angel of Vengeance] (1976), which replaces the role of Hamlet with a strong and determined female character. It is set against the background of a modernizing Turkish state, but still within a culture that showed some resistance to such modernity. This study examines how the director employs certain motifs, devices, and strategies (such as the use of classical music or westernized styles of dressing) to forward a modernizing agenda for the film. In particular, the idea of longing for an absent father (Atatürk and Hamlet's father) and contempt for the various puppets which have replaced him in politics (represented by Claudius and Polonius) is a key aspect of this adaptation. The 1976 film is analysed here in a wider historical context of Turkish Hamlets that have been adapted, staged, and produced in different genres and media with the modernizing aims of the Kemalist state in mind.

Keywords: adaptation, father complex, Hamlet, intercultural exchange, Kadın Hamlet: Intikam Meleği [Lady Hamlet: The Angel of Vengeance], Middle Eastern cinema, Turkish modernity, Turkish modernization, modern Turkish cinema, Shakespeare, translation

For Linda Hutcheon, adaptation is a "repetition without replication" and "an announced and extensive transposition of a particular work or works" $(2013,7)$. She defines the process of adaptation as “(re)interpretation," “(re-)creation," and "intertextual," and believes that "an adaptation is a derivation that is not derivative - a work that is second without being secondary. It is its own palimpsestic thing" (8-9). Fassbinder's approach to adaptation emphasizes reader-response methodology: "any given reader reads any book with his own sense of reality, and therefore any book evokes as many different fantasies and images as it has readers" $(1992,168)$. For him, the only possible option to "turn literature into film" is "through an unequivocal and single-minded questioning of the piece of literature and its language," "by scrutinizing the substance and the posture of the author's work," "by developing an imagination instantly recognizable as unique," and "by abandoning any futile attempt at 'consummating' the work of literature” (168-169). Similarly, Thomas Leitch problematizes the idea of fidelity in adaptation criticism. Underlining the unwitting privileging of source texts in these debates, Leitch, in his Film Adaptation and Its Discontents, maintains that "no matter how clever or audacious an adaptation is, the book will always be

Ә Open Access. (c) 2021 Adile Aslan Almond, published by De Gruyter. (c) BY-NC-ND This work is licensed under the Creative Commons Attribution-NonCommercial-NoDerivatives 4.0 International License. 
better than any adaptation because it is always better at being itself" $(2007,16)$. He even goes on later to propose that adaptation can be seen as a genre in its own right (Leitch 2008, 106). This article focuses on the only cinematic adaptation of Hamlet in Turkey, Kadın Hamlet: Intikam Meleği [Lady Hamlet: The Angel of Vengeance] (1976), ${ }^{1}$ and shows that it is a politically informed commentary - and a very secular one at that - on modern Turkey, despite its eccentric content. Previous works on the film, especially Tony Howard's Women as Hamlet (2007), are referred to throughout, as the article aims to update criticism on the film and its director in light of recent scholarship by drawing attention to the way modernization is implemented as both a theme and a device in itself.

\section{Female Hamlets}

A brief glance at the history of Hamlet on the theatre stage or on the silver screen shows a long list of female actresses who have played the eponymous character, dating back to the eighteenth century. While Charlotte Charke (1713-1760) recounted her experiences of playing Hamlet on the stage, Fanny Furnival, who played Hamlet in Dublin in 1741, is the first female Hamlet recorded in historical sources from the period. Furnival was closely followed by Sarah Siddons in 1775, Elizabeth Inchbald in 1780, and Jane Powell in 1796 (Howard 2007, 38-39). Sarah Bernhardt, in Paris, was the first woman to be filmed while playing Hamlet (Guntner 1998, 92). Eve Donne was the first female Hamlet broadcast on radio in 1923 (Howard 2007, 1). Whereas all of these actresses played Hamlet as a man, Anne Nielsen, a Danish actress who worked in German cinema, played Hamlet as a woman, the princess of Denmark in disguise as the Danish prince, in 1921, based on an argument proposed by Eward P. Vining in his The Mystery of Hamlet: An Attempt to Solve an Old Problem (1881; see Brode 2001, 118).

Turkish theatre and cinema have witnessed more than one female Hamlet to date. The first one was Ayla Algan, who played the role of Hamlet dressed in a man's clothes (as well as that of Ophelia) for the Municipal Theatre from 1962 to 1965. The second Turkish female Hamlet, in Kadın Hamlet, is more radical than her predecessors in that she is a woman playing a female Hamlet. More recently, the play Hamlet (1994), directed by Müge Gürman, was staged with two actors playing Hamlet in order to represent the character's split personality: one of the actors was dressed in the manner of Charlie Chaplin, whilst the other wore more

1 Hereafter referred to as Kadın Hamlet. 
feminine costumes (Arslan 2008, 177). Sarah Frankcom's 2014 production for Royal Exchange Theatre of Manchester was a gender and race-crossing Hamlet in which Maxine Peake embodied an androgynous Hamlet, albeit without any of the political content of the original play. Kadın Hamlet, on the other hand, is a gender-subversive adaptation embedded in a local political context. ${ }^{2}$ As we shall see, it is a unique adaptation with some unprecedented innovations. When it first appeared in 1976, the film received mixed reviews. Yet the hidden symbolism in its texture demands a careful reading and recognition as a politically informed, avant-garde adaptation.

\section{Metin Erksan and adaptation}

Metin Erksan was already an established figure on the Turkish cinematic scene when he shot the film. Interestingly, his debut film was a biography about the Bard of Turkish folk literature, Aş1k Veysel (1894-1973). He adapted many famous works of Turkish literature as films, one of which, Susuz Yaz [Dry Summer] (1963), earned Turkish cinema's first international recognition with its Berlin Golden Bear prize. Other adaptations include Emily Brontë's Wuthering Heights as Ölmeyen Aşk [Undying Love] (1966) and William Friedkin's Exorcist as Şeytan [The Devil] (1974), dubbed "the Turkish Exorcist." He also adapted five contemporary Turkish short stories by well-known Turkish writers into short-length films for the national TV channel in the 1970s. Erksan's oeuvre shows an imaginative combination of careful attention to central issues in Turkey (such as poverty, patriarchy, class issues, and rural problems) and more artistic tendencies (related to contemporary Turkish arts, literary adaptations, Western literary tradition, and Western cinema). He is associated with the Turkish National Cinema of the 1960s and 1970s, which advocated domestication in form and content, accompanied by the active sense of a socio-political task for film (Sayın 2011, 25-26). Kadın Hamlet was Erksan's penultimate film before 1977, when, dissatisfied with the film industry in Turkey and feeling that it underestimated his talent, he retired at the age of forty-eight.

Erksan originally named the film Kadın Hamlet. The subtitle Intikam Meleği [The Angel of Vengeance] was added later as a marketing tool to appeal to the cinema-goers of the time, who mostly consumed melodramatic films, come-

2 Howard claims that Frances de la Tour's Hamlet, directed by Robert Walker, was an attempt to embody the mood of the defeated Left in the UK after the election of Thatcher in 1979 (2005, 265-270). 
dies, thrillers, or softcore sex films. Gülşen Sayın shows how the main themes of Hamlet - familial strife, vengeance, love conflict, and power - can be adapted to the Turkish context through the melodrama genre (2011, 27). Tony Howard suggests that, as a result of the significance of the family in Turkish society, "the Elizabethan revenge ethic" can be rendered more precisely into Turkish rather than British modern society (Howard 2005, 211; similarly Sayın 2011, 27). Howard describes the film as "a bewildering cross of Shakespeare, the avant-garde," and "the least inhibited of all transgender Hamlets" (2005, 210-211).

Kadin Hamlet is the story of a woman whose father has been killed in the woods by her uncle. Returning from the United States, where she has studied drama, Hamlet attends the funeral of her father and, within a short time, witnesses, to her great dismay, the marriage of her mother and her uncle. When the ghost of her father appears and tells her who his murderer is, Hamlet's suspicions are confirmed, and she swears to take revenge. She fakes madness in order to prove her uncle's guilt and scorns her lover, Orhan, who later drowns himself. Hamlet employs tuluat (traditional Turkish theatre based on improvisation) actors to simulate the murder of her father on stage and drive Kasım to confess. However, Kasım decides to send her back to the United States to be killed by his underground friends in New York. Hamlet outdoes his plans and returns to the family mansion (a luxury mansion in an unnamed, indeterminate rural part of Turkey) to kill her uncle, who fatally shoots Hamlet's mother, mistaking her for Hamlet, in the woods. As it is a modern-day Hamlet set in 1970s Turkey, swords turn into rifles, ships translate into luxurious white cars, seaports into airports, and letters become phone calls. Geoffrey Wagner (cited in Cartmell and Whelehan 2010, 5) identifies three types of adaptation: transposition (absolute fidelity), commentary (intentional or unintentional alterations as a result of the interpretation of the director), and analogy (a new work of art with significant divergence from the source text). Erksan's film fits into the second category as he intentionally alters the source text in order to flesh out his perspective.

The film begins by depicting the murder of Hamlet's father in the woods and his sombre funeral, immediately followed by the carefree wedding of Kasim and Gönül, thereby solidifying the immoral motives of the uncle as early as the third scene in the film. The character of Gönül, on the other hand, is presented as gullible or passive, if not completely innocent, rather than evil, as she appears to be uncritically obeying Kasım's words throughout the scene. Hamlet keeps her distance from the newly-weds, looking disdainfully at the wedding spectacle, smoking a cigar with one hand while the other is in her pocket (an obvious gesture of disrespect), and standing on the verge of the wood, which becomes the symbol of her dead father. She is in a white suit with a striped shirt, a huge red tie, and an equally big red handkerchief hanging from her pocket. This bizarre suit can be 
considered a statement of Hamlet's views of the marriage of her mother and uncle so soon after her father's death. The cigar and suit might also be regarded as the director's attempt at conveying the famously complex character of Shakespeare's Hamlet. Erksan tries to show that Hamlet bears feminine and masculine traits simultaneously, and that she transcends the male/female dichotomy. On another level, Erksan might be endeavouring to inscribe the Turkish woman into modern Turkish history by reversing gender expectations. Indeed, Hamlet is by far the strongest character in the film.

One interesting detail about the wedding scene is the fact that flags are used as decorations and hung between trees. While these flags do not correspond to the national colours and forms of any known country, Erksan might have used them to insert the international quality of Hamlet's themes, or the transnational quality of Shakespeare's plays, into the film. A similar gesture in the film is the family's surname, which the audience sees on the grave of Hamlet's father. Evren means "universe" in Turkish. In this way, Erksan seems to be saying that he is trying to reach the universal by working through national material, as the only way to attain the universal is to first arrive at the national/local. ${ }^{3}$ The dialectic of the universal and national/local through Shakespeare recalls Laura Bohannan's "Shakespeare in the Bush" (1966) and how local productions of meaning are the first step toward reaching the universal level. The specific dates of the father's birth and death carry significant symbolic relevance for modern Turkish history, as will be explained later.

In a switch similar to that between Kasım's murder of his brother and the funeral, the wedding scene is followed by a break-up scene. Hamlet and Orhan are at the two opposite ends of an abandoned, broken quayside, enclosed by unfriendly nature in the form of vast water, unfertile soil, and distant hills. Everything the frame includes denotes a sense of doom and ruin. The barren surroundings as well as the distance between Hamlet and Orhan symbolize the desolate and sterile future of the lovers. The pebbles and water, and Orhan's delicate, insecure posture in the face of Hamlet's destructive determination and bewildering frustration, foreshadow Orhan's death as a result of their ill-fated love. The ghost of the dead father has not been mentioned yet. Hamlet distances herself from Orhan, even before she knows anything about the ghost of her father. In Erksan's interpretation, then, the ghost's effect on the relationship between Hamlet and Orhan is a secondary factor. This might also suggest that the ghost

3 Erksan was by no means the first director to discover this strategy of approaching universality through local content. A well-known example is the work of Jean-Pierre and Luc Dardenne, who have been working on their local material in order to reach universality since the early 1970s. 
is a by-product of Hamlet's train of thought. In fact, it is a curious fact that while Erksan changes all the other names, he keeps that of Hamlet intact, and in Turkish the word for "ghost" (hayalet) closely resembles "Hamlet."

The fifth scene of the film is the opening of the original play, namely the scene where the night guards see the ghost of the dead father and decide to inform Hamlet of it. Erksan, who is known to be a realist artist, here resorts to fantastic, surrealistic tools in order to translate the ghost scene into a visual text. The ghost is clad in a red-lined black cloak with a big black hat on his head and walks through heavy smoke, casting enigmatic glances in the direction of the guards. Sayın claims that Erksan "abstract[s] the setting from the real world, implying that the ghost might be Hamlet's own imagination" (2011, 32). It is true that Erksan uses unexpected elements in the composition of the ghost scene. Sayın, however, seems to miss the political allusions beneath the supernatural appearance. First of all, Erksan elucidates his position regarding the century-long divide between secularism and Islamism in Turkey: his Hamlet, as a Western-educated, cigar-smoking, bikini-wearing woman of action and determination, is a clear affirmation of the secular protagonist. Therefore, it is not surprising that Hamlet and her dead father are stripped of any religious symbolism throughout the film, including the Islamic white garments of the dead. One of the important cuts Erkan makes from the original play is that there is no praying scene after the mini-play "The Mouse-trap" is staged (in Shakespeare's original, a scene of prayer takes place after the court play is performed). Erksan seems to have deliberately removed all the religious elements in order to make his secular attitude clear in the context of the long secularism-vs-Islamism debate in Turkey. Second, Erksan seems to take the film's relation to the Turkish milieu very seriously, despite the disorienting melodramatic elements on the surface. Thus, comic elements are not appropriate for the gravity of the subject matter. Black seems to denote the significance of the father (who, in a modern Turkish context, is always associated with Mustafa Kemal Atatürk), as opposed to the usual comedic elements of ghosts clad in white. Any comedic conventions would have undermined his political stance. Indeed, Polonius is the only comic figure, and the most despicable character in the film.

Only in the ninth scene of the film does Hamlet finally meet the ghost of her father, who appears in a westernized suit, in contrast with the usual Turkish cinematic conventions. This points to the possibility that the dead father represents the "eternal father" of the Republic of Turkey, Mustafa Kemal Atatürk. Indeed, one of Atatürk's many modernizing measures in the 1920s and 1930s was the implementation of the laws of modern garments, where men were expected to wear a hat, suit, and tie. The film includes other characteristics of westernization as well. The female Hamlet is obviously a liberated woman. She has a degree in drama from the United States. She wears bikinis or see-through blouses. In fact, 
she wears suits with jackets and trousers for most of the film. She smokes and is entitled to her own opinion. Classical music represents Western arts in the film, which also include cinema and theatre. In many ways, this 1970s Turkish film deliberately portrays a Turkish woman who would be atypical for the Muslim, Anatolian, conservative audiences who came to watch it - the secular valency of the adaptation here is a clear counterfoil to the conservative nature of the society into which it was introduced.

\section{Erksan's contributions to the character of Hamlet: Madness scenes}

Most scholars agree that Erksan's Hamlet does not have any interiority. Unlike the brooding intellectual of Shakespeare's play who struggles with deeply philosophical questions regarding the existential conditions of the human race and is torn with self-doubt, Erksan's Hamlet is free from any kind of scepticism or metaphysical probing. She is confident, defiant, and self-composed from the first scene: there is no sense of unease or hesitation about her, and events unfold only to confirm her self-assurance. One of the tools Erksan uses in order to establish Hamlet's self-assurance is to change the character's roles and traits to the extent that Hamlet holds the reins of events in the plot. Erksan's Hamlet is important in furnishing a lead actress with such distinguished female agency and power at a time when feminism was still in its early stages in the West. Besides, Erksan makes some distinctive contributions to the character by highlighting Hamlet's madness and portraying it in unprecedented ways. Let us briefly examine the distinct qualities of some of these "madness" scenes.

After meeting Horatio and Bernardo (both are servants of Hamlet in the film) in the graveyard and asking them to keep the ghost story and her madness plan a secret, Hamlet appears in a red uniform (with possible connotations of both the Beatles' Sergeant Pepper and, closer to home, the state orchestras of the Turkish Republic), masquerading as a royal trumpeter among the trees and interrupting (and unsettling) Orhan, who is working on a realistic painting of the woods, to lecture him on the arts and the relationship between life and the arts. Upon ending her monologue/lecture on the arts and philosophy, she comes closer to Orhan and, in an unexpected manner, spills a box of red paint all over the canvas. Orhan is stunned and confounded: he cannot believe what he sees. Hamlet takes up her trumpet up and begins to play the same tune as that with which she interrupted him, and walks away. The importance of this scene lies in the fact that Erksan displaces or rearranges elements from the original play in an unexpected 
way. For example, in Shakespeare's play the trumpet is a prop that belongs to the Danish court. Here, it appears as a symbol of Hamlet's madness. Erksan bridges the courtly setting of the play and Hamlet's madness in an innovative way. Erksan also uses this scene to comment on the relationship between art and life. We can take the views expressed in this scene as Erksan's own, as a metacommentary on art. The parallels between the concepts in Hamlet's lecture and the themes in the original play, such as the discrepancy between the visible and reality, are noteworthy. The exaggerated acting of the Turkish actress who plays Hamlet draws attention to the theatricality of the whole scene and reminds the audience of the stage origins of the characters.

Erksan employs a similar strategy of bridging Shakespeare's Hamlet and his film by using the original elements in novel ways in the second madness scene, which immediately follows the first one. Hamlet is now dressed in medieval armour with helmet, breastplate, and sword, and walks toward the hammocks where her mother and uncle are sleeping under the trees. She wakes them up with a long shriek, swinging her sword in the air. The dichotomy between the real and the visible is again the subject matter here. Hamlet moves between Gönül and Kasım, holding a mirror against them in turn and asking questions about the discrepancies between the interior and exterior, investigating whether they feel guilty or afraid, for they know that the interior - what she calls the core hides murder, brutality, and barbarism. She breaks the mirror, bows in a knightly manner and walks away. As in the previous scene, the performance and theatricality of the scene are underlined by the acting, reminding the reader of the origin of the script. The costume of a medieval knight might even suggest the medieval origins of the play. In a way, then, Erksan brings about dynamic "cross-fertilisations" between two arts, instead of producing an example of culturally inferior, “impure" cinema (Cartmell and Whelehan 2010, 8).

In another scene, the audience is introduced to Hamlet's surreal outdoor bedroom. Hamlet sprawls on her bed, smoking and reading (the Shakespearean intellectual Hamlet at long last?). She looks seductive in translucent black tights and a red dress. Hamlet's seductive appearance reminds the audience of her mother's usual sensuality and sexually appealing glamour. This parallel between the mother and the daughter is underlined by the blue bed-cover, since the colour blue represents Gönül, as opposed to the red of Kasım's illegitimacy. A horn gramophone painted in rainbow colours plays "Makber” [Grave], a famous old Turkish song which "praise[s] the dignity and beauty of death, drawing a picture of death as a fantastic dreamland” (Sayın 2011, 33). When the Turkish Polonius arrives, Hamlet reprimands him for not knocking on the door before entering, and requests him to be as moral as a fishmonger (directly taken from the original text), and Polonius applauds. The mad princess makes sure to mention Orhan 
to Polonius, remarking that Orhan is a beautiful boy. In the next scene, Gönül and Kasım read a letter written by Hamlet, which Polonius has found in Orhan's pocket, telling him how much she loves him. Erksan mixes the scenes of the original play in order to create a powerful and conniving Hamlet who is in full control of events. When Gönül and Kasım announce their approval of the relationship, Orhan is sent to meet Hamlet in her wilderness.

When Orhan, pushed by Hamlet's parents and his own father, comes to talk to Hamlet, she is in an open field, lost in conducting Shostakovich's score from Kozintsev's Hamlet. She is wearing a classic tailcoat with trousers and bow tie. There are no orchestra members. The instruments are tied to sticks. Next, a tape recorder in motion appears on the screen. We then realize that the classical music Hamlet is conducting comes from a tape. Even the applause at the end of the concert to which Hamlet bows is from the tape. It is at this point that the female Turkish Hamlet "performs” the famous soliloquy of Shakespeare's Hamlet, "to be or not to be," which is worded closely to the original. While speaking her lines, she simulates stabbing herself. When finished, she rebukes Orhan for his naivety and tells him to forget about her.

The director's translation of the travelling troupe in Shakespeare's Hamlet into a traditional Turkish drama based on improvisation (tuluat) is another imaginative instance of adaptation to a local context. The resulting play-within-the-film is a highly creative interpretation of Shakespeare's "Mouse-trap." The play-within-the-play scene starts with Hamlet on the stage as the chorus leader. She wears a black robe covered with big white skulls. The stage is set up as a medieval castle, Erksan's subtle way of telling the audience about the medieval origins of the play. Hamlet starts the show with a discussion of the task of theatre: it is a mirror held up to the world to show the good and the bad, and only the ignorant are served by undermining the truth. Hamlet announces that the performance is made up of two parts: a song accompanied by dancing and acting, and a play. The musical show is performed by Hamlet, Rezzan, and Gül. Hamlet wears a black bowler hat, a white shirt, braces, and blue jeans. The song is a playback, but Hamlet does not try to lip-synch and only mimes the content of the lyrics with her gestures and body language, while dancing to and fro on the stage. Rezzan and Gül, wrapped all over in colourful striped unitards, rhythmically swing at the back. The song is a critique of corruption in a humorous fashion: the established system is a riddle no one can solve.

The song - sung by an openly leftist, famous Turkish pianist, Timur Selçuk is based on a poem by a well-known Turkish socialist-realist poet, Orhan Veli, who believed in poetry for the masses and was (through plain language) one of the modernizing figures of Turkish poetry in the twentieth century. In this way, Erksan inserts the socio-political climate of modern-day Turkey into his film version of 
Shakespeare's famous play and politically localizes its content. The ending is close to the original, except that rifles are used instead of swords. Hamlet and Osman shoot one another, and the latter confesses the fatal plan of Kasim, who shoots Gönül when he mistakes her for Hamlet in the woods. Finally, Hamlet shoots Kasım. The entire final act is accompanied by Shostakovich's score for Kozinstev's Hamlet.

\section{Conclusion}

Erksan's Kadın Hamlet removes Fortinbras and Denmark's war with Norway, and instead inserts the political climate of Turkey through deeply embedded symbols, and thereby localizes and vernacularizes the original. It is an avant-garde interpretation of Hamlet marked by melodrama, yet highly charged with some central socio-political issues of modern Turkey. Since its first complete translation (from French) into Turkish in 1908 (the year of the Young Turk Revolution) by Dr Abdullah Cevdet, a staunch secularist, Hamlet has been a symbol of modernization and westernization processes in Turkey. From the early twentieth century to the present, Hamlet has been (re)translated, adapted, staged, and interpreted in various media many times by different artists in Turkey. As Saliha Paker notes, "translations and productions of [Hamlet into Turkish] are very closely related not only to some of the major events in the Turkish theatre but also to important changes or developments in Turkish political and cultural history in the twentieth century" (1986, 89). Similarly, Savaş Arslan claims that the century-long divide between secularism and Islamism in modern Turkish politics can be closely traced in the history of Turkish Hamlets. He argues that

in Turkey, Shakespeare's works, and Hamlet in particular, have long been participants in a republican discourse, which invariably sides with secularism and modernization against religious and conservative movements. [...] translations and adaptations of Shakespeare's best-known play align themselves along ideological lines, marking out Hamlet as a quintessential modern political allegory. Informed by the legacy of Kemalism - the modernizing, secular tradition enshrined in the achievements and memory of Mustafa Kemal Atatürk, founder of the Turkish Republic - on the one hand, and complex issues of religion, geopolitical "orientation", and identity on the other, twentieth-century Turkish Hamlets are deeply inscribed by the country's turbulent political history. (Arslan 2008, 171)

Interestingly, while their observations are definitely apt for many Turkish instances of Hamlet, both Arslan and Paker overlook Erksan's Kadın Hamlet. Indeed, at first glance, Erksan's film does not seem to offer anything more than a populist, melodramatic adaptation of Shakespeare's play. However, as Howard suggests, the 
1970s were difficult years in Turkey. Due to strict censorship, the by-products of the 1971 military coup, and the ensuing political chaos, it was not easy to make a film with an overtly political message. Erksan's reaction to 1970 s Turkey was to disguise his political message in a melodramatic Hamlet. In his version, then, there is a longing for the long-gone idealized father, if we take Hamlet's father as representing Atatürk, and the politicians in his place are either illegitimate usurpers or clowns seeking power and material gain (Claudius and Polonius). The female Hamlet, a well-educated, liberated woman, is the embodiment of Atatürk's revolutions regarding the modernization of Turkish society. It comes as no surprise that Hamlet longs for her heroic father and derides those who have taken his place. Erksan manages to reflect this parallel between the admiring daughter and the idealized absent father by representing the two figures with strikingly analogous imagery. Perhaps what Kadin Hamlet most effectively communicates are the intricacies involved in political appropriation when it takes place in so-called “developing" societies - particularly when the objective is a secular liberal one, but located in a conservative Muslim culture. The director does not have to address any degree of familiarity with the original in his target audience, yet names such as "Shakespeare" have such a potent westernizing connotation in Turkey, that the "modernizing” of a Shakespeare play by a Turkish film director would simply be another step in an ideological direction already associated with the playwright.

\section{Works cited}

Arslan, Savaş. “Turkish Hamlets.” Shakespeare 4.2 (2008): 170-182.

Brode, Douglas. Shakespeare in the Movies: From the Silent Era to Today. New York: Berkley Boulevard Books, 2001.

Bohannan, Laura. "Shakespeare in the Bush: An American Anthropologist Set Out to Study the Tiv of West Africa and Was Taught the True Meaning of Hamlet." Natural History 75 (1966): 28-33.

Cartmell, Deborah, and Imelda Whelehan. Screen Adaptation: Impure Cinema. London: Macmillan International Higher Education, 2010.

Fassbinder, Rainer Werner. "Preliminary Remarks on Querelle." The Anarchy of Imagination: Interviews, Essays, Notes. By Fassbinder. Ed. Michael Töteberg and Leo A. Lensing. Baltimore and London: The Johns Hopkins University Press, 1992. 168-170.

Guntner, Lawrence J. "Expressionist Shakespeare: The Gade/Nielsen Hamlet (1920) and the History of Shakespeare on Film." Post Script: Essays in Film and the Humanities 17.2 (1998): 90-102.

Howard, Tony. Women as Hamlet: Performance and Interpretation in Theatre, Film and Fiction. Cambridge and New York: Cambridge University Press, 2007.

Hutcheon, Linda. A Theory of Adaptation. New York: Routledge, 2013. Kadın Hamlet: İtikam Meleği. Dir. Metin Erksan. Uğur Film, 1976. 
Leitch, Thomas. Adaptation and Its Discontents. Baltimore: The Johns Hopkins University Press, 2007.

Leitch, Thomas. "Adaptation: the Genre.” Adaptation 1.2 (2008): 106-120.

Paker, Saliha. "Hamlet in Turkey." New Comparison 2 (1986): 89-105.

Sayın, Gülşen. "Shakespeare in Turkish Cinema: A Cultural Transfer from Hamlet to The Angel of Vengeance (1976)." Journal of Adaptation in Film \& Performance 4.1 (2011): 17-37.

Adile Aslan Almond is a visiting instructor at Georgetown University in Qatar. She has published articles and book chapters on Turkish modernity. Her research interests are comparative modernisms, world literature, the Global South, Ottoman-Turkish literature, and Austrian literature. 